DOI: 10.22455/2500-4247-2016-1-3-4-82-91

УДК 821.14'02.0Гомер

ББК 83.3(0)321-8

\title{
THE GATES OF HORN AND IVORY: A GEOGRAPHICAL MYTH
}

\author{
Jörg Schulte \\ University of Cologne, Köln, Germany
}

Received:Jule 15, 2016

\section{ВОРОТА РОГОВЫЕ И ИЗ КОСТИ СЛОНОВОЙ: ГЕОГРАФИЧЕСКИЙ МИФ}

\author{
(C) 2016 г. Йорг Шульте \\ Университет Кёльна, Кёльн, Германия
}

Дата поступления статьи: 15 июля 2016 г.

\begin{abstract}
Аннотация: В статье предлагается новая интерпретация гомеровского мифа о вратах из рога и из слоновой кости из 19 книги «Одиссеи». Во-первых, утверждается, что рог (материал южных ворот в неоплатонических комментариях) может быть обнаружен под знаком Козерога. Менее очевидным является предположение о том, что и слоновая кость взята из астрономических мифов: это миф об Адонисе (который начинается с истории о статуе Пигмалиона из слоновой кости); миф об Эриманфском, Калидонском и Эфесском вепрях; миф об Орионе и о созвездии Большой Медведицы. В результате изучения мотива слоновой кости в греческой мифологии выдвигается гипотеза о том, что созвездие Большой Медведицы идентифицировалось с вепрем (с клыками из слоновой кости). Делается вывод о том, что уже во времена Гомера ворота роговые и из слоновой кости понимались как астрономический миф о самой северной и самой южной небесных точках.
\end{abstract}

Ключевые слова: гомеровский миф, миф об Адонисе, миф об Эриманфском, Калидонском и Эфесском вепрях, миф об Орионе и о созвездии Большой Медведицы.

Информация об авторе: Йорг Шульте - профессор-славист, директор Института Славистики Кёльнского университета, Кёльн, Германия, 50931, ул. Вейерталь, 137. E-mail: j.schulte@uni-koeln.de

Abstract: The articles proposes a new interpretation of the Homeric myth of the gates of horn and ivory that occurs in Book 19 of the Odyssey. It first argues that horn (the material of the southern gate in neoplatonic commentaries) can be found in the sign of Capricornus. More complex is the argument that also ivory (the material of the northern gate in neoplatonic commentaries) is derived from astronomical myths: the myths discussed are the myth of Adonis (beginning with the story about the ivory statue carved by Pygmalion), the myths of the Erymanthian, 
the Calydonian, and the Ephesian boars, the myth of Orion, and the myth of the constellation ursa major. An enquiry into the occurance of ivory in Greek mythology leads to the hypothesis that the constellation ursa major was identified with a boar (with ivory tusks). The hypothesis implies that the gates of horn and ivory were already at the times of Homer understood as an astronomical myth that described the northernmost and southernmost points of the sky.

Keywords: Homer myth, the myth of Adonis, the myths of the Erymanthian, the Calydonian, and the Ephesian boars, the myths of Orion and of the constellation ursa major

Information about the author: Jörg Schulte, Professor of Slavic Studies, Institute of Slavic Studies, University of Cologne, Weyertal 137, 50931 Cologne, Germany. E-mail: j.schulte@uni-koeln.de

The gates of horn and ivory belong to the oldest myths of European literature. For the first time, they occur in Book 19 of the Odyssey:

"Two gates there are for unsubstantial dreams, one made of horn and one of ivory. The dreams that pass through the carved ivory delude and bring us tales that turn to naught. Those that come forth through polished



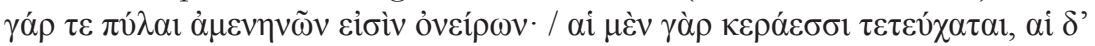

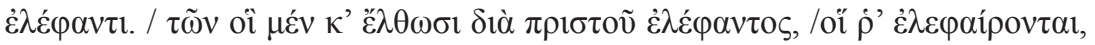

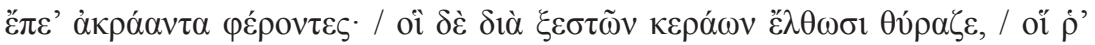

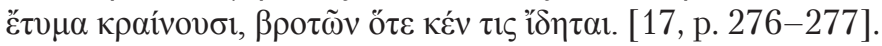

The history of their interpretation goes back to what is probably the first piece of literary scholarship, Porphyry's Commentary on the Cave of the Nymphs [21, p. 119-129]. A survey of the explanations from antiquity until the present as well as a comprehensive bibliography can be found in Ernest Highbarger's monograph [14; 16], in the seminal article by Anne Amory [1], and in the recent contributions by Anghelina Catalin [7] and Elena Ermolaeva [11].

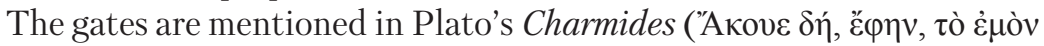

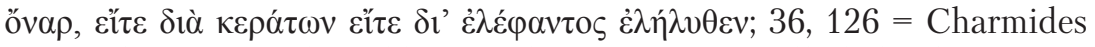
173a), they were reshaped by Vergil (Aen. VI, 898), alluded to by Horace (Hor. Carm. III, 27, 39f.), Statius (29, v. I, $326=$ Silvae, V, 4, 298-300), and Lucian [15, v. II, p. 185], and still frequently referred to during the Middle Ages [20] and the Renaissance [25, p. 146-148]. Eustathius of Thessalonica gave three explanations concerning the material of the gates [12, v. II, p. 219]. According to the first interpretation, "the reason that the poet [Homer] makes a horn gate the source of dreams which are true and accomplish true things is that there is a certain resemblance in sound



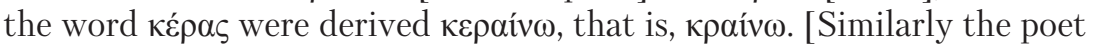
makes] an ivory gate the source of dreams which are false and deceptive, that is, which mislead, cheat, and only arouse expectations." [1, p. 4-6]. According to Eustathius, the verb which Penelope uses for "deceive," ć $\lambda \varepsilon$ - 


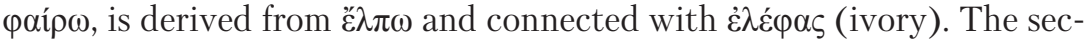
ond interpretation explains "the horn gate as the eyes, taking the part for the whole, in that the outermost covering of the eye is horny. And they say that the mouth is the ivory [gate] because of the ivory-coloured teeth, so that the wise Penelope is saying symbolically that the things which are seen as actual events are more trustworthy than things which are simply said to be so." The same interpretation is offered by Servius: "Per portam corneam oculi significantur, qui et cornei sunt coloris et duriores ceteris membris: nam frigus non sentiunt, sicut et Cicero dicit in libris de deorum natura. per eburneam vero portam os significatur a dentibus" [in Aen. VI, 883; 44, v. II, 122]. According to Eustathius's third explanation "the true [gate] is of horn, that is, transparent, whereas the false [gate] is of ivory, that is, blurred or opaque, because it is possible to see through horn $<\ldots>$ but not through ivory." Modern interpretations of the gates are, in their vast majority, variations on these three explanations given by Eustathius [28, p. 18-27].

An entirely different interpretation was given by Porphyry. In his Commentary on the Cave of the Nymphs; Porphyry identifies the gates of horn and ivory with two entrances of the cave of Ithaca. According to Porphyry, the gate of horn is directed towards the south and therefore ascribed to the southern wind Notus and to the constellation Capricornus; the gate of ivory opens towards the north and is correspondingly ascribed to Boreas, the constellation Cancer and to the moon, having its house in Cancer. The geographical assignations harmonize with those in Macrobius's Commentary on the Dream of Scipio, describing a southern gate in Capricornus and a northern gate in Cancer [26, p. 12]. In chapter 12, Macrobius describes how the souls descend from the Milky Way through the sign of Cancer and return there through the sign of Capricorn, these two signs being the points where the Milky Way intersects the ecliptic [26, p. 49].

The gates have thus received a geographical interpretation, but neither Porphyry nor Macrobius explain the material of the gates (horn and ivory), the distinctive feature of the gates in the Odyssey and Aeneid. Their interpretations are neo-platonic readings of a Homeric myth, and we tend to believe that they read a metaphysical and cosmographical meaning into the myth - which Homer could certainly not have had in mind.

In 1993, Godefroid de Callatay pointed out that the "horn" of the

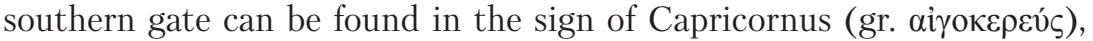
the southernmost sign of the zodiac [6, p. 321; 5, p. 207-36], whose approach was criticised by Wolfgang Hübner [19, p. 17]. Independently, as it seems, Anghelina Catalin, came to the conclusion that the two sets of gates mentioned in the Odyssey - the gates of horn and ivory and the gates of the sun-are identical, and that the gates of horn are derived from the constellation of Capricornus [7, p. 68-70]. Concerning the gates of 
ivory, Anghelina Catalin returns to the first explanation of Eustathius [7, p. 71-72].

A first hint towards a possible explanation of the gate of ivory might be contained in the sign of Capricornus. Capricornus (as the Latin caper) is etymologically clearly the same word as the Greek кó $\pi \rho$ s (the boar) which is confusing from a zoological point of view. In four of the eight passages of the Iliad, the boar is given the double name $\sigma \tilde{v} \varsigma$ кó $\pi \rho ı \varsigma$, pig-goat, which did not mean anything else than a "pig with horns". This would agree with Chantraine's explanation that the first part of $\sigma \tilde{\varsigma} \varsigma$ кó $\pi \rho ı \varsigma$ was abandoned, when the goat was designated by $\tau \rho \alpha$ ó $о \varsigma$ and lost its former

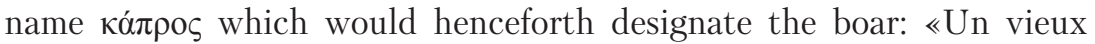

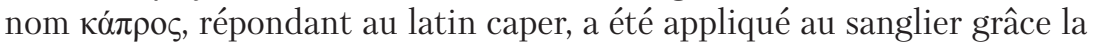

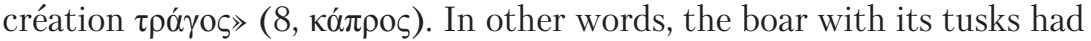
its name from the horns of the goat. A similar confusion existed over a long period for the animal with the biggest tusks that gave the name to the Greek word for ivory, the elephant. Until the end of antiquity there were controversies, whether the tusks of the elephant were teeth or horns; Pausanias assumes that the elephant's tusks are horns [34, p. 444-445= Per. V.12.1-3], Pliny speaks of cornua elephanti [38, p. $188=$ Nat. hist. 8.71 and 18.2]. The distinction was clear only regarding the material, $\dot{\varepsilon} \lambda \dot{\varepsilon}-$ pas being understood as the hard, white material of the tooth opposed to the transparent material of horn.

If both the boar and the elephant were believed to have "horns," it is an obvious question to ask whether there is any evidence that the tusk of the boar has ever been related to $\dot{\varepsilon} \lambda \dot{\varepsilon} \varphi \alpha \varsigma$ in the meaning of ivory, the only meaning in which the word is used by Homer [43, p. 32-63]. Ovid compared the boar's tusk to the teeth of the elephant when he described the Caledonian boar: "Dentes [apris] aequantur dentibus Indis" [33, v. 1, p. $426=$ Met. VIII, 289]. But what do we know about the tusk of the boar in the Greek world? We know from the Iliad that tusks of boars were used for the decoration of helms (Il. X, 262-265). Today, the animals associated with ivory are elephant, hippopotamus, walrus, narwhal, and mammoth (as fossil ivory)-but how can we know if the tusk once made the boar a part of the noble group of animals which have teeth of $\dot{\varepsilon} \lambda \dot{\varepsilon} \varphi \alpha \varsigma$, ivory [23, p. 8-9 and passim]? One possible answer is contained in the myth of Adonis as told in the tenth book of the Metamorphoses.

The genealogy of Adonis begins with the story about the sculptor Pygmalion who falls in love with a statue carved in ivory by his own hand. Three flames ascend when Venus answers his prayers and transforms the ivory statue into a living body: "Flamma ter accensa est apicemque per aera duxit. / ut rediit, simulacra suae petit ille puellae / incumbensque toro dedit oscula" [33, v. II, p. $84=$ Met. X, 279-281]. The statue bears Pygmalion a son, Paphos. The son of Paphos is Kinyras, the daughter of Kinyras is Myrrha. Out of the incest of Kinyras and Myrrha, Adonis is 
born. Adonis is killed by the tusk of a boar, fulfilling, as Ovid explicitly says, the punishment for the sin of his ancestor Pygmalion, Pygmalion's love for the ivory statue: " $<\ldots>$ vel, si credetis, facti quoque credite poenam” [33, v. II, p. $86=$ Met. X, 303]. This punishment had been predicted when Adonis, born from the incestuous love between Kinyras and his daughter Myrrha, grew into a beautiful young man: "Iam iuvenis, iam vir, iam se formosior ipso est, / iam placet et Veneri matrisque ulciscitur ignes" [33, v. II, p. $100=$ Met. X, 523-524]. The "revenge of his mother's fire" is generally understood as referring to Myrrha's forbidden love but there is a clear echo to the "fire of Venus" that had animated Pygmalion's ivory. The primal punishment is, of course, not directed against Venus but against Adonis, the last descendant of the family of Pygmalion: The circle of the Adonis myth is closed with an ivory clasp - and the myth of Adonis is a strong argument that the tusk of the boar was regarded equal to ivory in antiquity. Unfortunately, there are no earlier versions of the myth in which the connection between the ivory of the statue and the ivory of the boar's tusk would be equally clear [32, p. 95; 10, p. 13-16; 45, p. 52-55], only the descent of Adonis from Pygmalion (the king of Cyprus) is testified by Apollodorus [2, p. 84-85 = Bibl. III, 182].

That the family history from Pygmalion to Paphos, to Kinyras, to Myrrha and finally to Adonis is a myth about ivory had been well understood by the anonymous author (writing in late antiquity) of the poem


Theocritus and usually printed as Theocritus's thirtieth idyll. This satirical text tells how the boar brought by the Graces in chains before the mourning Venus expresses his regret for the death of Adonis, which was not his intention. "I never wanted to wound him", the boar says, "but I saw him like a statue, / and could not suffer the burning, / for his thigh was

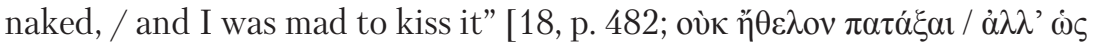

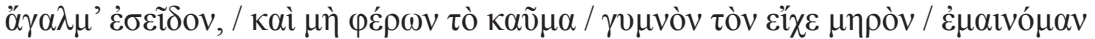
$\varphi \imath \lambda \tilde{\alpha} \sigma \alpha 1]$. How could the fate of the family be made clearer than by the reference to the statue (ö $\gamma \alpha \lambda \mu \alpha)$ ? In the small poem, the boar points out to Venus, that it was not he but his tusks that killed Adonis, and therefore asks her to break them out. The last lines of the poem report that the boar

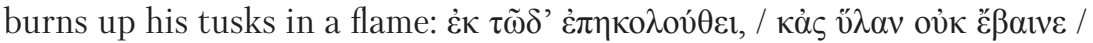

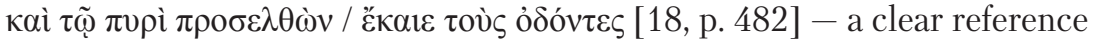
to the flame that transformed the ivory of Pygmalion. This version can be found in all Renaissance editions and Latin translations. Some modern translators seem to have disliked the cruel image of the burning tusk and made the boar - correcting the mistakes that allegedly occurred in the transmission of the last lines - "bear the flame of love" [22, p. 158].

How can the tusk of the boar help to explain the geographical dimen-


defines the gate of horn in the south, we are looking for ivory in the north- 
ern sky. This part of the argument-the question how the boar is related the geographic north-is the most difficult part of the explanation. The same question is posed by the Odyssey, when, at the very end of book 14, Ulysses goes to sleep under the hollow rock with the boars, where he finds

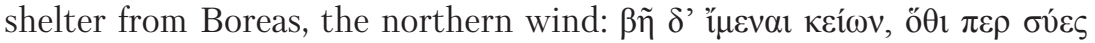

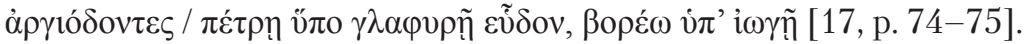

There are three possible answers. The first has been provided by several scholars, perhaps most notably by Jean Richer [40, p. 105; 41, p. 8283] and Jacques Bonnet [3, p. 26 and 50] who have claimed that the boar represents the geographic north in Indogermanic mythology. The second possible answer builds on the close relation between the bear and the boar in Greek mythology. The bear or, more precisely, the constellation of the big dipper (ursa maior) has given its name to the arctic and to the northern winds (aparctias, septentrio) and has indisputably become the mythological representation of the north. The bear and the boar share some mythological features: they are both sacred to Artemis. Girls disguised as bears served in the temple of Artemis [45, passim]. Callisto is the companion of Artemis in the astronomical myth, a fact that has given rise to investigations suggesting the equality of Callisto and Artemis [42]. If Artemis can be regarded as moon goddess, the astrological house of the moon in Cancer, the most northern sign in the zodiac-a connection well-known from early statues of Artemis [9] - becomes an additional argument for the mythological connection between Artemis and the geographical north. Both the bear and the boar have their home in the Erymanthian mountains (Ov. Met. V, 608), the hunting ground of Artemis (Od. VI, 102) and therefore share the same attribute. The three famous boars of Greek mythology, the Erymanthian, the Calydonian, and the Ephesian boars are closely connected to Artemis. Mythological features shared by the bear and the boar suggest that not only the bear but also the boar has been part of the mythological representation of the geographic north.

The third possible answer is connected to the astronomical myth of Orion. In the controversial discussions of astronomical myths, the myth of Orion is maybe the only myth that is widely acknowledged as having an astronomical foundation [39, p. 350-363; 30, p. 7; 38, p. 192]. The relation between Orion and Ursa Major is the most conspicuous between any constellations. Orion is setting during the culmination of Ursa Major. Therefore, the bear is watching Orion on the shield of Achilles: 'Арктóv



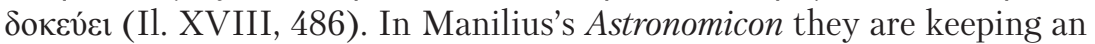
eye on each other: "Arctos et Orion adversis frontibus ibant" [27, p. 44-45 $=$ Astr. I, 502]. Orion is killed either by Artemis (Od. V, 118) or by a scorpion (Arat. Phaen. 636-644). The scorpion that kills Orion is obviously the constellation of Scorpio that rises when the constellation Orion is setting. If Adonis (killed by a boar) was, as orientalists have claimed [(31, 
p. $278 ; 4$, p. 457; 24, t. I, p. 247; 13, p. 115-119], at a certain period regarded as identical with Orion, there is at least some evidence that, at a certain period, the constellation Ursa Major has been interpreted as a boar.

The three possible answers to the question how the boar (and with him the material of his tusks) is related the geographical north are by no means a philological proof. The only way to solve this question is to combine judgements of classical philologists and orientalists. It seems, however, that the answers allow a hypothesis concerning the Homeric gates of horn and ivory and their first interpretation. There is evidence that the gates of horn and ivory have always been a geographical or cosmological myth, and that the neo-platonic commentaries of Porphyry and Macrobius which are-with good reason-being suspected of over-interpreting ancient myth, in this case make a correct connection: The gate of horn belongs to the geographic south, to the sign of Capricornus, and the gate of ivory belongs to the geographic north. The Satyricon of Petronius contains a passage in which the constellation of Cancer and the mythological image of the boar are closely connected: At the banquet of Trimalchio (chapter XL) the dishes are modelled and arranged according to the signs of the zodiac, providing a decoration "worthy of Aratos." Trimalchio, the host of the banquet, mentions twice that he had been born under the sign of Cancer; immediately after the description of the zodiacal decorations he has a boar brought in, which had been given a reprieve the night before. Trimalchio (himself the son of a slave) therefore takes the cap of Dionysos Liber and moves it from his head to the head of the boar: "in cancro ego natus sum. ideo multis pedibus sto, et in mari et in terra multa possideo; $<$...> hic aper, cum heri summa cena eum vindicasset, a convivis dimissus <est $>$; itaque hodie tamquam libertus in convivium revertitur. $<\ldots>$ Trimalchio 'Dionyse' inquit 'liber esto'. puer detraxit pilleum apro capitique suo imposuit. tum Trimalchio rursus adiecit: 'non negabitis me' inquit 'habere Liberum patrem”' [35, p. 76-78].

The material of ivory, however, is not derived from the sign of Cancer only but from the ancient tradition that interpreted the constellation Ursa Major as a boar, which is echoed in the myths of the Erymanthian, the Calydonian and the Ephesian boars, as well as in the myth of the boar that killed Thammuz-Adonis. This explanation of the myth would also indicate that the Homeric texts contain a small portion of the kind of knowledge that his neo-platonic interpreters were looking for and that was overlooked or dismissed by Servius, Eustathius, and their followers. The first piece of "literary scholarship," Porphyry's Commentary on the Cave of the Nymphs, would have revealed a layer in the Homeric text that concerns the very essence of the Homeric text. In the Odyssey, the imagery of horn and ivory is not limited to the famous gates but includes bow of Ulysses (made of horn) and Penelope, who is "whiter than ivory" and takes a key of ivory in order to fetch the bow for Ulysses. Their marriage 
bed is decorated with ivory. Porphyry would have offered an approach to literary texts that-despite of all the doubtless over-interpretations that it brought about-cannot be entirely dismissed from philological scholarship.

\section{REFERENCES}

1 Amory, Anne. 'The Gates of Horn and Ivory'. Yale Classical Studies 20 (1966): 3-57.

2 Apollodorus. The Library. Edited by James George Frazer. Cambridge, Mass.: Harvard Univ. Press, 2001. 403 p.

3 Bonnet, Jacques. Artémis d'Ephèse et la légende des sept dormants. Paris: P. Geuthner, 1977. 198 p.

4 Brown, Robert. 'The Celestial Equator of Aratos'. Transactions of the Ninth Congress of Orientalists 1892, 445-85.

5 Callataÿ, Godefroid de. 'Les douze grands dieux de l'Énéide'. Res Antiquae 2 (2005): 207-36.

6 Idem. 'Le zodiaque de l'Enéide'. Latomus 52 (1993): 318-49.

7 Catalin, Anghelina. 'The Homeric Gates of Horn and Ivory'. Museum Helveticum 67, no. 2 (2010): 65-72.

8 Chantraine, Pierre. Dictionnaire étymologique de la langue grecque. Paris: Klinksieck, 1968. $1368 \mathrm{p}$.

9 Deonna, Waldemar. 'The Crab and the Butterfly: A Study in Animal Symbolism'. Journal of the Warburg and Courtauld Institutes 17, no. 1/2 (1954): 47-86.

10 Dinter, Annegret. Der Pygmalion-Stoff in der europäischen Literatur: Rezeptionsgeschichte einer Ovid-Fabel. Heidelberg: Winter, 1979. 171 p.


560-569)'. Philologia Classica 7 (2007): 3-14.

12 Eustathius Thessalonicensis. Commentarii ad Homeri Odysseam: Ad fidem exempli Romani editi. Edited by Alfred Stallbaum. Lipsiae: J. A. G. Weigel, 1825. 443 p.

13 Fontenrose, Joseph Eddy. Orion: The Myth of the Hunter and the Huntress. Berkeley: University of California Press, 1981. 315 p.

14 Haller, Benjamin. 'The Gates of Horn and Ivory in Odyssey 19: Penelope's Call for Deeds, Not Words'. Classical Philology 104, no. 4 (2009): 397-417.

15 Harmon, Austin Morris, ed. Lucian in Eight Volumes. Cambridge, Mass.: Harvard University Press, 1968. 519 p.

16 Highbarger, Ernest Leslie. The Gates of Dreams: An Archaeological Examination of Vergil, Aeneid 6, 893-899. Baltimore: Johns Hopkins Press, 1940. 136 p.

17 Homerus. The Odyssey. Edited by Augustus Taber Murray and George E. Dimock. Cambridge, Mass.: Harvard University Press, 1995, 496 p.

18 Hopkinson, Neil, ed. Theocritus, Moschus, Bion. Cambridge, Mass.: Harvard University Press, 2015. 590 p.

19 Hübner, Wolfgang. Crater Liberi: Himmelspforten und Tierkreis. München: Verlag der Bayerischen Akademie der Wissenschaften, 2006. 68 p.

20 Kruger, Steven F. Dreaming in the Middle Ages. Cambridge: Cambridge University Press, 1992. 254 p. 
21 Lamberton, Robert. Homer the Theologian: Neoplatonist Allegorical Reading and the Growth of the Epic Tradition. Berkeley: University of California Press, 1986. 363 p.

22 Lang, Andrew, ed. Theocritus, Bion and Moschus. London: Macmillan and Company, 1909. $210 \mathrm{p}$.

23 Lapatin, Kenneth D. S. Chryselephantine Statuary in the Ancient Mediterranean World. Oxford: Oxford University Press, 2001. 242 p.

24 Lenormant, François. Les origines de L'histoire d'aprés la Bible et les traditions des peuples orientaux. Paris: Lévy, 1880. 630 p.

25 Lepage, John L. The Revival of Antique Philosophy in the Renaissance. New York: Palgrave Macmillan, 2012. 282 p.

26 Macrobius, Ambrosius Theodosius. Commentarii in Somnium Scipionis. Edited by James A. Willis. Stutgardiae: Teubneri, 1994. 253 p.

27 Manilius, Marcus. Astronomica. Edited by George P. Goold. Cambridge, Mass.: Harvard University Press, 1977. 528 p.

28 Miller, Patricia Cox. Dreams in Late Antiquity: Studies in the Imagination of a Culture. Princeton: Princeton University Press, 1994. 274 p.

29 Mozley, J. H., ed. Statius in Two Volumes. Cambridge, Mass.: Harvard University Press, 1955. $458 \mathrm{p}$.

30 Müller, K. D. ‘Orion'. Rheinisches Museum für Philologie 2 (1834): 1-29.

31 Olcott, William Tyler. Star Lore of All Ages. New York: G.P. Putnam’s Sons, 1911. 449 p.

32 Ovidius Naso, Publius. Metamorphosen: Kommentar (Buch X-XI). Edited by Franz Bömer. Heidelberg: Winter, 1980. 441 p.

33 Idem. Metamorphoses. Edited by G. P. Goold and Frank Justus Miller. Cambridge, Mass.: Harvard University Press, 1977. 496 p.

34 Pausanias. Description of Greece. Volume 2: Books III-V. Edited by William H. S. Jones. Cambridge, Mass.: Harvard University Press, 2000. 560 p.

35 Petronius Arbiter. Satyricon. Edited by E. H. Warmington. Cambridge, Mass.: Harvard University Press, 1975. 544 p.

36 Plato. Charmides, Laches, Lysis. Edited by Karl Friedrich Hermann. Lipsiae: Teubneri, 1881. $88 \mathrm{p}$.

37 Plinius Secundus, Gaius. Natural History: Books XVII-XIX. Edited by Harris Rackham. Cambridge, Mass.: Harvard University Press, 1992. 400 p.

38 Possanza, D. Mark. Translating the Heavens: Aratus, Germanicus, and the Poetics of Latin Translation. New York: Peter Lang, 2004. 279 p.

39 Renaud, Jean-Michel. Le Mythe d'Orion: Sa signification, sa place parmi les autres mythes grecs et son apport à la connaissance de la mentatlité antique. Liège: CIPL, 2004. $454 \mathrm{p}$.

40 Richer, Jean. Géographie sacrée dans le monde romain. Paris: Trédaniel, 1985. 462 p.

41 Idem. Géographie sacrée du monde grec: Croyances astrales des anciens grecs. Paris: Guy Trédaniel, 1983. 331 p.

42 Sale, William. 'Callisto and the Virginity of Artemis'. Rheinisches Museum Für Philologie 108 (1965): 11-35.

43 Scullard, Howard Hayes. The Elephant in the Greek and Roman World. London: Thames \& Hudson, 1974. 288 p. 
44 Servius. In Vergilii Carmina Commentarii. Edited by Georg Christian Thilo and Hermann Hagen. Lipsiae \& Berolini: Teubner, 1923. 650 p.

45 Sourvinou-Inwood, Christiane. Studies in Girls' Transition: Aspects of the Arkteia and Age Representation in Attic Iconography. Athens: Kardamitsa, 1988. 159 p.

46 Spahlinger, Lothar. Ars latet arte sua: Untersuchungen zur Poetologie in den Metamorphosen Ovids. Stuttgart: Teubner, 1996. 378 p.

47 Westermann, Antonius. МҮЯОГРАФОI: Scriptores poeticae historiae graeci. Brunsvigiae: Westermann, 1843. 451 p. 